\title{
ANALISIS KAPASITAS TAMPUNGAN DAN KINERJA WADUK UNTUK MEMENUHI KEBUTUHAN AIR TANAMAN NANAS DI PT. GREAT GIANT PINEAPPLE
}

\section{Analysis of Reservoir Capacity and Performance of Reservoirs to Supply Water Needs of Pineapple Plant in PT. Great Giant Pineapple}

\author{
Rani Sahfitri, Sugeng Prijono* \\ Jurusan Tanah, Fakultas Pertanian, Universitas Brawijaya Jl. Veteran No.1 Malang 65145 \\ *Penulis korespondensi: spj-fp@ub.ac.id
}

\begin{abstract}
The reservoir is one of the water sources that can be used for irrigation activities. PT. Great Giant Pineapple utilizes the reservoir function to provide water for irrigation activities. In an era that is increasingly developing now, many things can support success in the agricultural sector. Cropwat for window 8.0 application and ArcGis is one proof of technological advancements in this era. The results of this study were to determine the capacity of a reservoir by using two different methods, i.e. bathymetry and DEM, and to find out the performance of the reservoir used for irrigation activities based on pineapple plant water requirements. This research was conducted at PT. Great Giant Pineapple, Terbanggi Besar, Lampung, from October to November 2019. Based on the results of the study, it is recommended to use the bathymetry method for reservoirs with water-filled conditions and using the DEM method for water-empty reservoirs, and it is known that the performance of a reservoir will be affected by the amount of outflow and inflow that occurs in the reservoir and the large reservoir capacity.
\end{abstract}

Keywords : bathymetry, Cropwat for Windows, digital elevation models, reservoirs, water balance

\section{Pendahuluan}

Sumberdaya air merupakan salah satu kunci untuk mendukung perkembangan dari ekonomi, industri, dan pertanian. Pada sektor pertanian kebutuhan air memiliki peran yang sangat penting. Peran keberadaan air bagi sektor pertanian adalah untuk irigasi. Dalam mendapatkan hasil pertanian yang baik ketersediaan air harus mencukupi kebutuhan tanaman. Grasia et al. (2011), mengungkapkan salah satu faktor penentu untuk mendapatkan keberhasilan hasil pertanian yang memuaskan adalah cukupnya ketersediaan air.

PT. Great Giant Pineapple merupakan perusahaan swasta yang memiliki perkebunan nanas terbesar di Indonesia yang eksistensinya telah diakui oleh dunia internasional melalui hasil produk olahan nanas. Dalam menunjang keberhasilan produksinya sumberdaya air memiliki peranan penting untuk memenuhi kebutuhan air tanaman nanas melalui kegiatan irigasi. Kebutuhan air tanaman nanas dapat diketahui dengan model Cropwat for Windows yang dikembangkan oleh Irrigation and Development Institute (IIDS). Tusi et al. (2012), mengatakan Cropwat for Windows didesain untuk menghitung evapotranspirasi dan kebutuhan air tanaman untuk merencanakan dan memanajemen jadwal irigasi. PT. Great Giant Pineapple memanfaatkan fungsi waduk yang terdapat pada lokasi perkebunan untuk kegiatan irigasi guna memenuhi kebutuhan air tanaman nanas.

Waduk atau lebung merupakan suatu tempat besar untuk menyimpan air persedian untuk memenuhi berbagai kebutuhan. Waduk adalah tampungan yang berfungsi untuk menyimpan air pada waktu kelebihan agar dapat 
dipakai pada waktu yang diperlukan (Rudianto, 2019). Waduk dapat terjadi secara karena proses alami ataupun buatan manusia. Topografi dasar waduk alami tentu saja tidak menunjukkan keadaan yang seragam. Waduk yang memiliki fungsi dalam menyimpan air juga memiliki batasan kapasitas penyediaannya. Keadaan dasar topografi waduk alami yang tidak seragam ini tentu saja mempersulit untuk menghitung kapasitas tampungan dari waduk itu sendiri.

PT. Great Giant Pineapple memanfaatkan waduk alami untuk menyediakan air dalam memenuhi berbagai kebutuhan khususnya adalah kegiatan irigasi. Sering sekali saat memanfaatkan fungsi waduk untuk kegiatan irigasi PT. Great Giant Pineapple dipertemukan dengan masalah kehabisan pasokan air pada waduk tersebut. Hal ini terjadi karena PT. Great Giant Pineapple tidak memiliki data kapasitas tampungan waduk alami. Salah satu cara untuk menghitung kapasitas tampungan waduk adalah dengan melakukan perhitungan volume waduk dengan pengukuran batimetri waduk menggunakan drone boat. Tidak hanya itu kemampuan Drone dapat dimanfaatkan untuk mengetahui keadaan topografi dasar permukaan waduk kering dengan menyajikan bentuk ketinggian permukaan bumi secara digital atau yang disebut dengan Digital Elevation Model (DEM).

Mencermati masalah yang terjadi dibutuhkan suatu penelitian untuk menghitung kapasitas tampungan waduk yang berada pada lokasi perkebunan PT. Great Giant Pineapple serta mengetahui kinerja waduk tersebut dapat menyediakan air untuk memenuhi kebutuhan air tanaman nanas. Hasil penelitian ini diharapkan dapat memberikan informasi data awal kapasitas tampungan serta gambaran kinerja waduk lokasi penelitian dan dapat menerapan metode yang lebih tepat dalam menghitung kapasitas tampungan waduk dengan dua kondisi yang berbeda.

\section{Bahan dan Metode}

\section{Tempat dan waktu penelitian}

Penelitian dilaksanakan di PT. Great Giant Pineapple Jalan Terbanggi Besar, Lampung Tengah, Lampung, Indonesia (Gambar 1). Penelitian dilaksanakan pada bulan Agustus sampai dengan bulan Desember 2019. Penelitian dilakukan pada dua kondisi waduk yang berbeda, yaitu waduk kosong (lokasi 116) dengan luas waduk 0.4 ha dan waduk kondisi terisi air (lokasi 86) dengan luas waduk 0.83 ha.

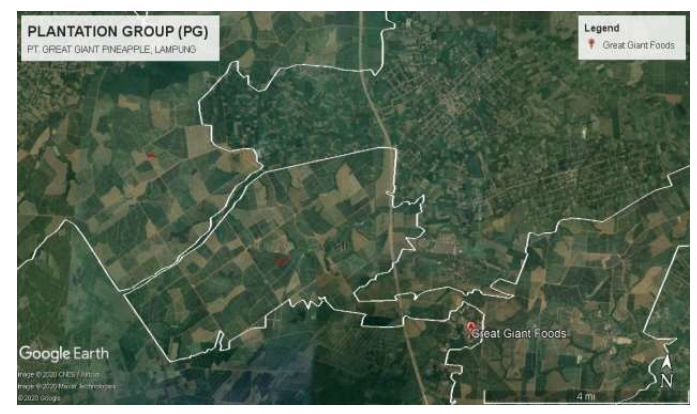

Gambar 1. Peta lokasi penelitian.

\section{Alat dan bahan}

Alat yang dimanfaatkan dalam kegiatan penelitian ini meliputi software ArcMap 10.3, software AgiSoft Photoscan, Drone Boat, GPS antena, Drone Dji Phantom 3 Pro, Cropwat for Windows 8.0 dan Microsoft Excel. Bahan yang menunjang dalam penelitian ini berupa Foto udara waduk, Peta batas waduk, Data titik kedalaman waduk, dat DEM waduk, Data Curah Hujan, dan Data Evaporasi.

\section{Pelaksanaan penelitian}

Metode yang digunakan dalam pelaksanaan penelitian kali ini meliputi tahap pra-survei, tahap survei, dan tahap pasca survei. Tahap prasurvei dilakukan obeservasi awal waduk lokasi penelitian untuk mengetahui mobilitas yang dapat dilakukan pada waduk lokasi penelitian. Tahap survei meliputi pengambilan foto udara waduk dengan menggunakan drone dji phantom 3 pro dan perumuman data titik kedalam dengan menggunakan drone boat, sedangkan tahap pasca survei meliputi kegiatan pengolahan foto udara dan data DEM, perhitungan volume waduk dengan ms. excel, simulasi kebutuhan air tanaman nanas dengan applikasi cropwat for windows, dan menghitung kinerja waduk.

\section{Pengambilan foto udara}

Pengambilan foto udara ini menerbangkan drone DJI Phantom 3 pro dengan kamera resolusi 12 megapixel dengan ukuran pixel $0.02 \times 0.02 \mathrm{~m}^{2}$ 


\section{Jurnal Tanah dan Sumberdaya Lahan Vol 8 No 1: 135-148, 2021 e-ISSN:2549-9793, doi: 10.21776/ub.jts1.2021.008.1.17}

untuk waduk lokasi 116 dan $2.6 \times 2.6 \mathrm{~m}^{2}$ pada waduk lokasi 86 serta pengambilan foto udara ini dilakukan dengan ketinggian 80-100 meter dan overlay sebesar $80 \%$. Sebelum melakukan penerbangan Drone Dji Phantom 3 Pro perlu ditentukan Ground Check Point (GCP). GCP merupakan titik ikat lapangan yang dapat meningkatkan akurasi dari model yang dihitung sehingga foto udara pada area yang diukur dapat menunjukkan hasil yang mengarah pada lokasi sebenarnya di lapangan.

\section{Pengolahan foto udara}

Foto udara diolah dengan menggunakan aplikasi Agisoft Photoscan Pro 1.3. Aplikasi Agisoft Photoscan Pro 1.3 memiliki fungsi untuk menggabungkan foto udara (mosaic) serta dapat mengolah data digital elevation model (DEM) dari foto udara yang telah digabungkan tersebut. Langkah awal yang dilakukan adalah menambahkan foto yang akan diolah selanjutnya melakukan reference setting, kalibrasi kamera, serta meluruskan posisi foto. Selanjutnya melakukan build mesh. Kemudian melakukan pembuatan titik penanda GCP dan mengoptimasi kesejajaran kamera, selanjutnya adalah build dense clouds diikuti dengan build texture, build DEM, dan build orthomosaic. Pengolahan foto udara diahkiri dengan melaukan export orthomosaic dan export DEM.

\section{Pengambilan data titik kedalaman}

Pengambilan data titik kedalaman ini dilakukan dengan metode random sampling point atau pengambilan data titik kedalaman secara acak hingga titik sampel pada luasan waduk menjadi jenuh dan telah mewakili kondisi keadan topografi waduk dengan menerapkan alat drone boat.

\section{Pengolahan data titik kedalaman}

Pengolahan data titik kedalaman dilakukan dengan menggunakan aplikasi ArcMap 10.3. Langkah pertama yang dilakukan adalah merekap data titik koordinat dan data titik kedalaman dengan menggunakan excel. Selanjutnya input orthomosaic waduk, data batas lebung dan masukan file excel data titik kedalaman dengan menggunakan add XYdata. Kemudian menyesuaikan sistem proyeksi pada data titik kedalaman yang telah di input. Selanjutnya shp data titik kedalaman diinterpolasi menggunakan tools "Topo to Raster" dengan memasukan data titik dan data polygon batas lebung. Hasil dari pengolahan data titik kedalaman ini adalah data kontur dengan jarak antar kontur sebesar 0,1, selanjutnya dengan menggunakan fitur data management tools untuk mengubah line menjadi polygon dengan cara pilih feature lalu feature to polygon dan menghitung luas perkontur menggunakan fitur calculate geometry pada property pilih "area". Berikutnya gabungkan 2 shp dengan fitur "intersect" dengan masukan data shp kontur dan shp feature to polygon.

\section{Pengolahan data DEM}

Pengolahan data DEM ini dilakukan dengan menggunakan aplikasi ArcMap 10.3. Langkah pertama yang dilakukan adalah memasukan orthomosaic waduk dan DEM waduk. Selanjutnya membuat kontur dari data DEM yang telah dimasukan yaitu dengan fitur 3D analyst tools lalu raster surface dan pilih kontur. Masukan nilai interval kontur sebesar 0,1. Kemudian dilakukan untuk menghitung luas perkontur dengan menggunakan fitur data management tools untuk mengubah line menjadi polygon dengan cara pilih feature lalu feature to polygon dan selanjutnya untuk menghitung luas perkontur menggunakan fitur calculate geometry pada property pilih "area". Berikutnya gabungkan 2 shp dengan fitur "intersecl" dengan masukan data shp kontur dan shp feature to polygon.

\section{Perhitungan volume waduk}

Perhitungan volume waduk dilakukan dari artibut data intersect yang merupakan penggabungan antara shp kontur dan shp feature to polygon selanjutnya disalin pada Microsoft Excel. Perhitungan volume waduk diawali dengan menjumlahkan luas kontur pada nilai elevasi yang sama selanutnya menghitung total luas perkontur kumulatif. Kemudian hitung volume waduk dari luas perkontur kumulatif dengan persamaan:

"Vx, y, .. n $=\frac{1}{3} \times D \times(\mathrm{Fn}+\mathrm{F}(\mathrm{n}+1)+\sqrt{\mathrm{Fn} \times \mathrm{F}(\mathrm{n}+1)}$.

Setelah didapatkan volume waduk pada setiap elevasi, hitung total volume waduk dengan menggunakan persamaan:

"Vtotal $=$ Vx + Vy+.... Vn. (2) 


\section{Jurnal Tanah dan Sumberdaya Lahan Vol 8 No 1: 135-148, 2021 e-ISSN:2549-9793, doi: 10.21776/ub.jts1.2021.008.1.17}

\section{Perhitungan analisis kebutuhan air tanaman nanas}

Pertama yang dilakukan untuk menganalisis kebutuhan air tanaman nanas adalah menjalankan software cropwat 8.0 dan klik icon climate selanjutnya masukan data klimatologi berupa data country, data station, data altitude, data latitude, data longitude, data temperatur, data kelembaban relative, data kecepatan angin, dan data lama penyinaran matahari. Kemudian klik icon rain dan masukan data total hujan. Selanjutnya klik icon crop dan masukan data tanaman kemudian edit tanggal penanaman. Langkah terahkir adalah memasukan data tanah dengan cara klik icon soil. Hasil analisis kebutuhan air dapat diketahui dengan klik icon CWR.

\section{Analisis data}

Analisis data ini dilakukan dari data perhitungan jumlah kapasitas tampungan waduk menggunakan aplikasi Microsoft Excel. Analisis data ini juga untuk mengetahui kinerja waduk serta mengetahui jumlah kapasitas tampungan waduk.

\section{Hasil dan Pembahasan}

\section{Kondisi umum wilayah}

PT. Great Giant Pineapple yang terletak pada kabupaten Lampung Tengah yang memiliki ketinggian 25-75 mdpl dan kemiringan 0-3\%. Nurjayanti dan Buce (2012), menambahkan Lampung Tengah merupakan daerah dataran alluvial yang terbentuk dari sungai-sungai besar seperti Way Sekampung, Way Tulang Bawang, dan Way Mesuji. Lokasi penelitian terletak dalam formasi geologi Formasi Terbanggi (Qpt) didasarkan dari peta geologi skala 1:250.000 lembar Menggala. Formasi Terbanggi (Qpt) itu sendiri terdiri atas batupasir dengan sisipan batulempung. Sebagian besar bahan induk pada lokasi penelitian berupa tuff masam. Tuff masam merupakan jenis batuan sedimen masam dari bahan vulkan yang komposisinya didominasi oleh mineral campuran opak dan kuarsa (Widitya et al., 2018). Mineral opak dan kuarsa merupakan mineral sukar lapuk sehingga saat tanah mengalami pelapukan yang lebih lanjut maka mineral opak dan kuarsa akan tetap ada. Mineral tahan lapuk disebabkan mineral- mineral tersebut memiliki ikatan silika-oksigen (Si-O) yang kuat, dan secara umum mencerminkan rendahnya kesuburan tanah (Rachim, 2007). Lokasi penelitan didominasi oleh tanah Ultisol. Ultisol yang memiliki bahan induk bersifat masam seperti batuan sedimen pasir, batuan beku granit ataupun batuan tuf, akan cenderung mempunyai kandungan fraksi pasir yang tinggi.

\section{Model perhitungan volume waduk menggunakan metode batimetri dan DEM}

Penerapan metode batimetri pada dua kondisi waduk yang berbeda yaitu waduk terisi air (lokasi 86) dan kosong air (lokasi 116). Volume waduk lokasi 86 yang disajikan pada Tabel 1. Berdasarkan analisis pemetaan batimetri yang telah dilakukan pada waduk lokasi 86 yang merupakan waduk dengan kondisi terisi oleh air menunjukkan volume waduk saat dilakukan pengukuran atau volume aktual menunjukkan nilai sebesar $11534.16 \mathrm{~m}^{3}$ atau setara dengan 11534160 liter. Luas genangan air saat dilakukan pengukuran sebesar $8389 \mathrm{~m}^{2}$ atau setara dengan 0.83 ha. Hasil perhitungan menunjukkan semakin dalam elevasi maka luas perkontur semakin kecil sebaliknya semakin tinggi elevasi maka luasan perkontur semakin besar. Begitu pula dengan nilai volume waduk, semakin besar luas perkontur maka nilai volume waduk meningkat. Pengukuran titik kedalaman ini dilakukan dengan pantulan gelombang suara oleh fish finder (alat drone boat). Fish finder adalah teknologi untuk mendeteksi objek bawah air yang bekerja berdasarkan prinsip suara (akustik) tidak hanya itu kelebihan dari alat ini adalah mampu menjadikan data yang bersifat real time (Suteja et al., 2019). Penyajian peta batimetri pada lokasi 86 berupa kontur dapat dilihat pada Gambar 2, dengan interval kontur 0,1 m dimulai dari yang terkecil yaitu $0 \mathrm{~m}$ hingga yang terdalam $2.5 \mathrm{~m}$. Peta kontur batimetri ini dibuat dengan menginterpolasikan 306 titik yang dianalisis menjadi 26 titik kedalaman yang diolah dengan aplikasi ArcGIS. Soeprobowati (2012), menyatakan bahwa peta batimetri dapat menunjukkan keadaan relief dasar daerah perairan dengan garis-garis kontur kedalaman. Lokasi 116 menunjukkan keadaan kering dimana waduk tersbut dalam kondisi kosong air, dengan demikian perumunan batimetri tidak dapat dilakukan. Data titik kedalaman tersebut 


\section{Jurnal Tanah dan Sumberdaya Lahan Vol 8 No 1: 135-148, 2021 e-ISSN:2549-9793, doi: 10.21776/ub.jts1.2021.008.1.17}

diperoleh dari pengukuran yang dilakukan oleh fish finder (alat drone boat). Alat drone boat dapat beroperasi apabila berada diatas permukaan air. Drone boat dilengkapi dengan komponen fish finder memiliki fungsi untuk mengukur titik kedalaman dengan memantulkan gelombang suara. Hamim (2011), mengungkapkan bahwa fish finder ialah alat akustik yang mana perambatan gelombang suara dapat terjadi didalam suatu medium yaitu adalah air. Setiap waduk pasti memiliki kapasitas tampungan yang berbeda-beda karena dipengaruhi oleh kedalaman dan luasan dari waduk itu sendiri. Hasil perhitungan volume waduk dengan metode DEM pada lokasi 116 disajikan pada Tabel 2. Digital Elevation Model (DEM) dapat menggambarkan topografi dari permukaan bumi yang mana pada DEM memiliki data elevasi dari ketinggian permukaan bumi. (DEM) adalah dataset kartografi digital dalam tiga (XYZ) koordinat dan telah diturunkan dari garis kontur (Gandhi dan Sarkar, 2016). Peta kontur pada waduk lokasi 116 dapat dilihat pada Gambar 3. Berdasarkan hasil perhitungan dari Tabel 2. dibuat lengkung kapasitas waduk yang disajikan pada gambar 4. Lengkung kapasitas menunjukkan volume kapasitas tampungan maksimum waduk sampai pada elevasi $31.1 \mathrm{~m}$ adalah $4861.90 \mathrm{~m}^{3}$ dengan luas genangan 3811 $\mathrm{m}^{2}$. Lengkung kapasitas waduk merupakan grafik yang menghubungkan luas daerah genangan (luas perkontur) dengan volume tampungan terhadap elevasinya (Putra, 2018). Hasil perhitungan volume waduk dengan menerapkan metode DEM pada waduk terisi oleh air (lokasi 86) yang disajikan oleh Tabel 3.

Tabel 1. Hasil perhitungan luas perkontur dan volume waduk lokasi 86.

\begin{tabular}{|c|c|c|c|c|}
\hline $\begin{array}{c}\text { Elevasi Waduk } \\
\text { (m) }\end{array}$ & Luas Perkontur $\left(\mathrm{m}^{2}\right)$ & $\mathrm{h}(\mathrm{m})$ & $\begin{array}{c}\text { Volume } \\
\text { Waduk }\left(\mathrm{m}^{3}\right)\end{array}$ & Volume Kumulatif $\left(\mathrm{m}^{3}\right)$ \\
\hline-2.50 & 5.00 & 0.10 & 0.60 & 0.00 \\
\hline-2.40 & 7.00 & 0.10 & 0.94 & 0.60 \\
\hline-2.30 & 12.00 & 0.10 & 4.65 & 1.54 \\
\hline-2.20 & 94.00 & 0.10 & 10.04 & 6.19 \\
\hline-2.10 & 107.00 & 0.10 & 22.24 & 16.23 \\
\hline-2.00 & 363.00 & 0.10 & 63.73 & 38.47 \\
\hline-1.90 & 959.00 & 0.10 & 118.39 & 102.20 \\
\hline-1.80 & 1424.00 & 0.10 & 186.17 & 220.59 \\
\hline-1.70 & 2337.00 & 0.10 & 261.15 & 406.76 \\
\hline-1.60 & 2896.00 & 0.10 & 328.84 & 667.91 \\
\hline-1.50 & 3697.00 & 0.10 & 464.19 & 996.75 \\
\hline-1.40 & 5656.00 & 0.10 & 548.51 & 1414.88 \\
\hline-1.30 & 5316.00 & 0.10 & 560.05 & 1914.59 \\
\hline-1.20 & 5890.00 & 0.10 & 612.20 & 2474.65 \\
\hline-1.10 & 6357.00 & 0.10 & 657.38 & 3086.85 \\
\hline-1.00 & 6793.00 & 0.10 & 695.49 & 3744.23 \\
\hline-0.90 & 7118.00 & 0.10 & 723.57 & 4439.72 \\
\hline-0.80 & 7354.00 & 0.10 & 744.73 & 5163.28 \\
\hline-0.70 & 7541.00 & 0.10 & 762.83 & 5908.02 \\
\hline-0.60 & 7716.00 & 0.10 & 779.69 & 6670.85 \\
\hline-0.50 & 7878.00 & 0.10 & 794.39 & 7450.53 \\
\hline-0.40 & 8010.00 & 0.10 & 806.79 & 8244.93 \\
\hline-0.30 & 8126.00 & 0.10 & 818.29 & 9051.72 \\
\hline-0.20 & 8240.00 & 0.10 & 828.35 & 9870.01 \\
\hline-0.10 & 8327.00 & 0.10 & 835.80 & 10698.36 \\
\hline 0.00 & 8389.00 & 0.10 & 279.63 & 11534.16 \\
\hline
\end{tabular}

Keterangan: $\mathrm{h}=$ interval kontur $(\mathrm{m})$ 
Jurnal Tanah dan Sumberdaya Lahan Vol 8 No 1: 135-148, 2021

e-ISSN:2549-9793, doi: 10.21776/ub.jts1.2021.008.1.17

Tabel 2. Hasil perhitungan luas perkontur dan volume waduk lokasi 116.

\begin{tabular}{|c|c|c|c|c|}
\hline $\begin{array}{c}\text { Elevasi Waduk } \\
\text { (m) }\end{array}$ & $\begin{array}{c}\text { Luas Perkontur } \\
\left(\mathrm{m}^{2}\right)\end{array}$ & $\mathrm{h}(\mathrm{m})$ & $\begin{array}{c}\text { Volume Waduk } \\
\left(\mathrm{m}^{3}\right)\end{array}$ & $\begin{array}{l}\text { Volume Kumulatif } \\
\qquad\left(\mathrm{m}^{3}\right)\end{array}$ \\
\hline 29.60 & 2552.00 & 0.10 & 261.52 & 0.00 \\
\hline 29.70 & 2679.00 & 0.10 & 273.48 & 261.52 \\
\hline 29.80 & 2791.00 & 0.10 & 284.09 & 535.01 \\
\hline 29.90 & 2891.00 & 0.10 & 293.69 & 819.09 \\
\hline 30.00 & 2983.00 & 0.10 & 302.54 & 1112.78 \\
\hline 30.10 & 3068.00 & 0.10 & 310.74 & 1415.32 \\
\hline 30.20 & 3147.00 & 0.10 & 318.59 & 1726.06 \\
\hline 30.30 & 3225.00 & 0.10 & 326.34 & 2044.65 \\
\hline 30.40 & 3302.00 & 0.10 & 333.94 & 2370.99 \\
\hline 30.50 & 3377.00 & 0.10 & 341.34 & 2704.94 \\
\hline 30.60 & 3450.00 & 0.10 & 348.64 & 3046.28 \\
\hline 30.70 & 3523.00 & 0.10 & 355.89 & 3394.92 \\
\hline 30.80 & 3595.00 & 0.10 & 363.14 & 3750.82 \\
\hline 30.90 & 3668.00 & 0.10 & 370.39 & 4113.96 \\
\hline 31.00 & 3740.00 & 0.10 & 377.54 & 4484.36 \\
\hline 31.10 & 3811.00 & 0.10 & 384.64 & 4861.90 \\
\hline 31.20 & 3882.00 & 0.10 & 391.74 & 5246.55 \\
\hline 31.30 & 3953.00 & 0.10 & 398.84 & 5638.29 \\
\hline 31.40 & 4024.00 & 0.10 & 405.99 & 6037.14 \\
\hline 31.50 & 4096.00 & 0.10 & 413.10 & 6443.13 \\
\hline 31.60 & 4166.00 & 0.10 & 420.10 & 6856.22 \\
\hline 31.70 & 4236.00 & 0.10 & 427.10 & 7276.32 \\
\hline 31.80 & 4306.00 & 0.10 & 434.10 & 7703.42 \\
\hline 31.90 & 4376.00 & 0.10 & 441.24 & 8137.51 \\
\hline 32.00 & 4449.00 & 0.10 & 448.55 & 8578.76 \\
\hline 32.10 & 4522.00 & 0.10 & 455.75 & 9027.30 \\
\hline 32.20 & 4593.00 & 0.10 & 462.60 & 9483.05 \\
\hline 32.30 & 4659.00 & 0.10 & 469.05 & 9945.64 \\
\hline 32.40 & 4722.00 & 0.10 & 474.75 & 10414.69 \\
\hline 32.50 & 4773.00 & 0.10 & 479.90 & 10889.44 \\
\hline 32.60 & 4825.00 & 0.10 & 485.15 & 11369.33 \\
\hline 32.70 & 4878.00 & 0.10 & 490.20 & 11854.48 \\
\hline 32.80 & 4926.00 & 0.10 & 261.52 & 12344.68 \\
\hline
\end{tabular}

Keterangan: $\mathrm{h}=$ interval kontur $(\mathrm{m})$

Berdasarkan hasil perhitungan dari Tabel 3, menunjukkan bahwa kenaikan luas perkontur pada setiap elevasinya tidak stabil melainkan menunjukkan nilai yang fluktuatif. . Hal ini diindikasikan karena data DEM hanya dapat menggambarkan topografi pada permukaan bumi namun topografi yang terbentuk dibawah permukaan air tidak dapat digambarkan oleh DEM. Croneborg et al. (2015), menjelaskan
DEM dibuat untuk menunjukkan kondisi topografi permukaan tanah sedangkan DEM dibawah permukaan air disebut dengan batimetri. Curten (2017) menambahkan data DEM adalah data ketinggian diatas dari permukaan laut berbeda dengan batimetri yang dapat memetakan daerah dibawah permukaan air dan dapat dipresentasikan dengan permukaan raster. 
Jurnal Tanah dan Sumberdaya Lahan Vol 8 No 1: 135-148, 2021

e-ISSN:2549-9793, doi: 10.21776/ub.jts1.2021.008.1.17

Tabel 3. Hasil perhitungan luas perkontur dan volume waduk lokasi 86.

\begin{tabular}{|c|c|c|c|c|}
\hline $\begin{array}{c}\text { Elevasi Waduk } \\
(\mathrm{m})\end{array}$ & $\begin{array}{l}\text { Luas Perkontur } \\
\left(\mathrm{m}^{2}\right)\end{array}$ & $\mathrm{h}(\mathrm{m})$ & $\begin{array}{c}\text { Volume Waduk } \\
\left(\mathrm{m}^{3}\right)\end{array}$ & $\begin{array}{c}\text { Volume Kumulatif } \\
\left(\mathrm{m}^{3}\right)\end{array}$ \\
\hline 12 & 2.00 & 1 & 2839.50 & 0.00 \\
\hline 13 & 8387.00 & 1 & 8383.50 & 2839.50 \\
\hline 14 & 8380.00 & 1 & 8378.00 & 11223.00 \\
\hline 15 & 8376.00 & 1 & 8374.00 & 19601.00 \\
\hline 16 & 8372.00 & 1 & 8370.00 & 27975.00 \\
\hline 17 & 8368.00 & 1 & 8373.50 & 36345.00 \\
\hline 18 & 8379.00 & 1 & 8382.00 & 44718.50 \\
\hline 19 & 8385.00 & 1 & 8386.00 & 53100.50 \\
\hline 20 & 8387.00 & 1 & 8386.50 & 61486.50 \\
\hline 21 & 8386.00 & 1 & 8386.50 & 69873.00 \\
\hline 22 & 8387.00 & 1 & 8386.00 & 78259.50 \\
\hline 23 & 8385.00 & 1 & 8384.50 & 86645.50 \\
\hline 24 & 8384.00 & 1 & 8384.50 & 95030.00 \\
\hline 25 & 8385.00 & 1 & 8383.00 & 103414.50 \\
\hline 26 & 8381.00 & 1 & 8379.50 & 111797.50 \\
\hline 27 & 8378.00 & 1 & 8379.50 & 120177.00 \\
\hline 28 & 8381.00 & 1 & 8384.00 & 128556.50 \\
\hline 29 & 8387.00 & 1 & 8385.50 & 136940.50 \\
\hline 30 & 8384.00 & 1 & 8384.00 & 145326.00 \\
\hline 31 & 8384.00 & 1 & 8385.00 & 153710.00 \\
\hline 32 & 8386.00 & 1 & 8386.00 & 162095.00 \\
\hline 33 & 8386.00 & 1 & 8385.00 & 170481.00 \\
\hline 34 & 8384.00 & 1 & 8385.50 & 178866.00 \\
\hline 35 & 8387.00 & 1 & 8386.00 & 187251.50 \\
\hline 36 & 8385.00 & 1 & 8386.00 & 195637.50 \\
\hline 37 & 8387.00 & 1 & 8386.50 & 204023.50 \\
\hline 38 & 8386.00 & 1 & 8386.50 & 212410.00 \\
\hline 39 & 8387.00 & 1 & 8388.00 & 220796.50 \\
\hline 40 & 8389.00 & 1 & 8387.50 & 229184.50 \\
\hline 41 & 8386.00 & 1 & 8386.00 & 237572.00 \\
\hline 42 & 8386.00 & 1 & 8385.50 & 245958.00 \\
\hline 43 & 8385.00 & 1 & 8385.50 & 254343.50 \\
\hline 44 & 8386.00 & 1 & 8386.50 & 262729.00 \\
\hline 45 & 8387.00 & 1 & 8388.00 & 271115.50 \\
\hline 46 & 8389.00 & 1 & 8389.00 & 279503.50 \\
\hline 47 & 8389.00 & 1 & 8389.00 & 287892.50 \\
\hline 48 & 8389.00 & 1 & 8389.00 & 296281.50 \\
\hline 49 & 8389.00 & 1 & 8389.00 & 304670.50 \\
\hline 50 & 8389.00 & 1 & 8389.00 & 313059.50 \\
\hline 51 & 8389.00 & 1 & 8389.00 & 321448.50 \\
\hline 52 & 8389.00 & 1 & 2839.50 & 329837.50 \\
\hline
\end{tabular}

Keterangan: $\mathrm{h}=$ interval kontur $(\mathrm{m})$ 
Jurnal Tanah dan Sumberdaya Lahan Vol 8 No 1: 135-148, 2021 e-ISSN:2549-9793, doi: 10.21776/ub.jts1.2021.008.1.17

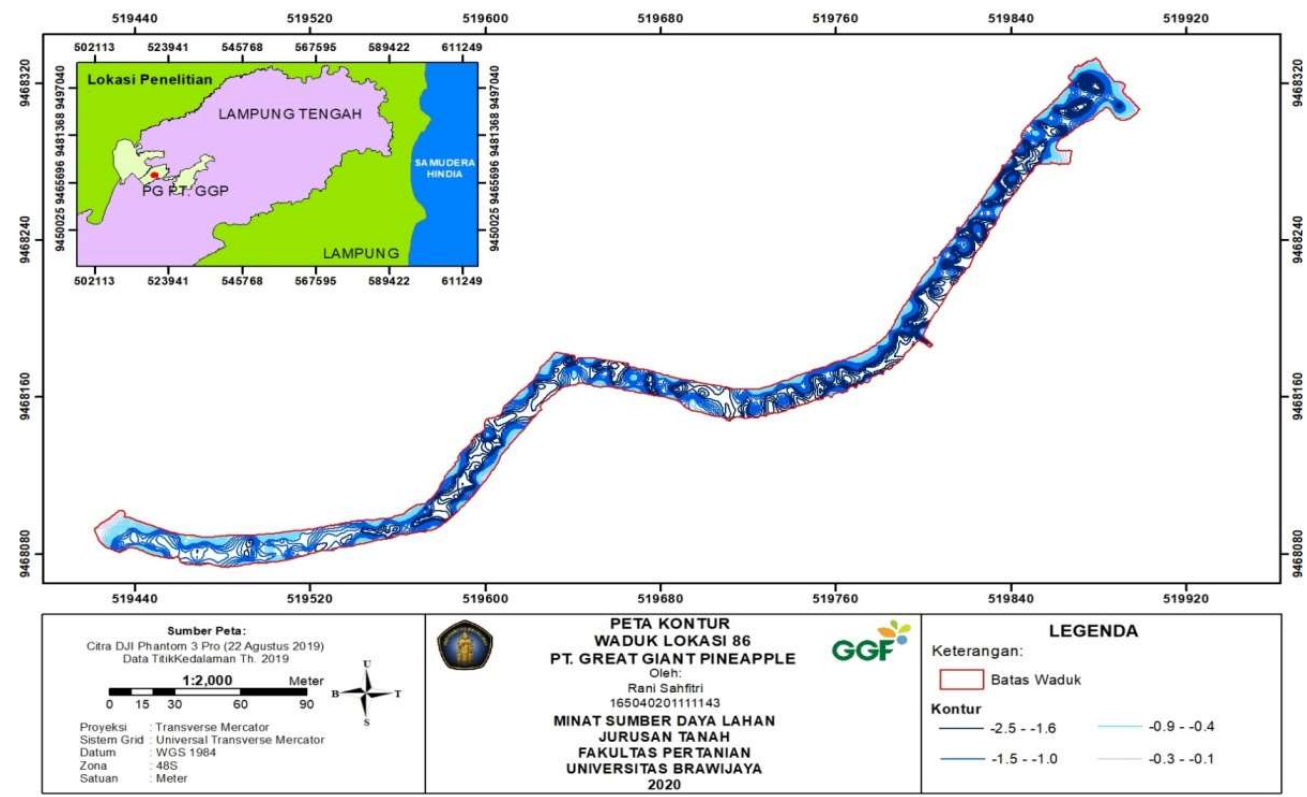

Gambar 2. Peta kontur waduk lokasi 86.

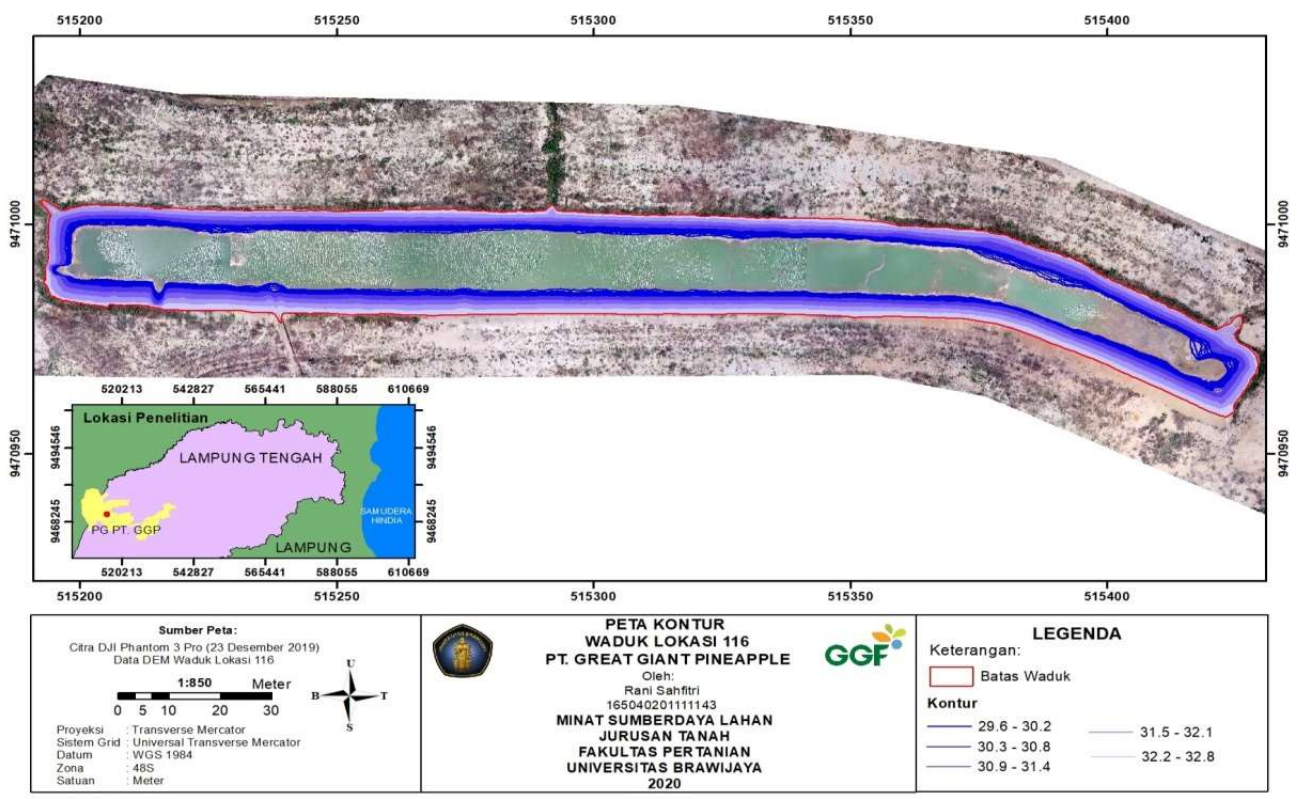

Gambar 3. Peta kontur waduk lokasi 116. 
Jurnal Tanah dan Sumberdaya Lahan Vol 8 No 1: 135-148, 2021

e-ISSN:2549-9793, doi: 10.21776/ub.jts1.2021.008.1.17

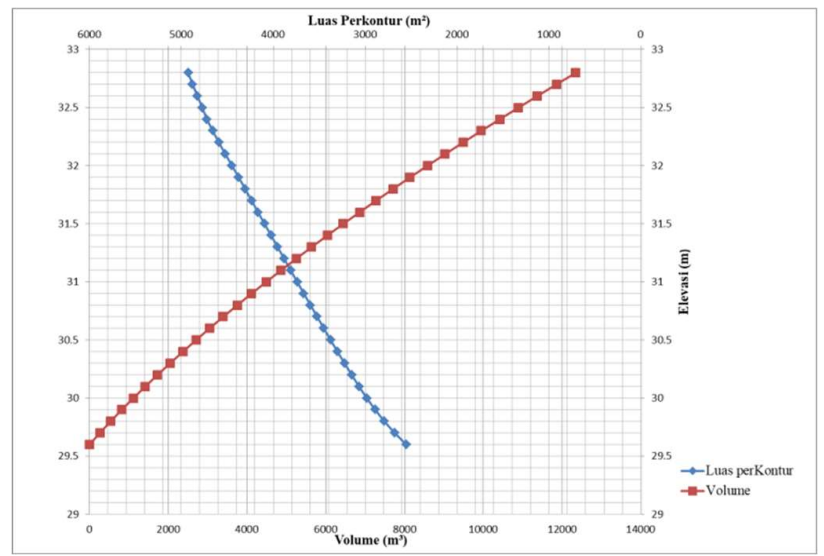

Gambar 4. Lengkung kapasitas waduk lokasi 116.

\section{Kebutuhan air tanaman nanas dan kebutuhan air itigasi}

Terjadinya proses transpirasi dan proses evaporasi terjadi secara bersamaan sehingga tidak dapat dipisahkan satu dengan yang lainnya, maka dari itu kehilangan air yang disebabkan oleh kedua proses ini disebut menjadi evapotranpirasi (ET). Perhitungan jumlah kebutuhan air tanaman menggunakan aplikasi Cropwat version 8.0yang disajikan pada Tabel 4.

Tabel 4. Kebutuhan air tanaman nanas dengan Software Cropwat 8.0.

\begin{tabular}{cccccccc}
\hline Bulan & Decade & Stage & Kc & $\begin{array}{c}\text { ETc } \\
\left(\mathbf{m m ~ d a y}^{-1}\right)\end{array}$ & $\begin{array}{c}\text { ETc } \\
\left(\mathbf{m m ~ d e c}^{-1}\right)\end{array}$ & $\begin{array}{c}\text { Eff rain } \\
\left(\mathbf{m m ~ d e c}^{-1}\right)\end{array}$ & $\begin{array}{c}\text { Irr. Req. } \\
\left(\mathbf{m m ~ d e c}^{-1}\right)\end{array}$ \\
\hline Jan & 3 & Init & 0.3 & 1.03 & 8.2 & 33.9 & 0 \\
Feb & 1 & Init & 0.3 & 1.06 & 10.6 & 55.9 & 0 \\
Feb & 2 & Init & 0.3 & 1.08 & 10.8 & 62.6 & 0 \\
Feb & 3 & Init & 0.3 & 1.10 & 8.8 & 60 & 0 \\
Mar & 1 & Init & 0.3 & 1.11 & 11.1 & 56 & 0 \\
Mar & 2 & Init & 0.3 & 1.12 & 11.2 & 54.2 & 0 \\
Mar & 3 & Deve & 0.3 & 1.12 & 12.3 & 54 & 0 \\
Apr & 1 & Deve & 0.3 & 1.11 & 11.1 & 56.8 & 0 \\
Apr & 2 & Deve & 0.3 & 1.11 & 11.1 & 57.9 & 0 \\
Apr & 3 & Deve & 0.3 & 1.14 & 11.4 & 46.2 & 0 \\
May & 1 & Deve & 0.3 & 1.18 & 11.8 & 30.8 & 0 \\
May & 2 & Deve & 0.3 & 1.21 & 12.1 & 19.4 & 0 \\
May & 3 & Deve & 0.3 & 1.16 & 12.7 & 18.2 & 0 \\
Jun & 1 & Deve & 0.3 & 1.09 & 10.9 & 18 & 0 \\
Jun & 2 & Deve & 0.3 & 1.03 & 10.3 & 15.6 & 0 \\
Jun & 3 & Deve & 0.3 & 1.09 & 10.9 & 13.8 & 0 \\
Jul & 1 & Deve & 0.3 & 1.16 & 11.6 & 11.6 & 0 \\
Jul & 2 & Deve & 0.3 & 1.22 & 12.2 & 9.6 & 2.6 \\
Jul & 3 & Mid & 0.3 & 1.21 & 13.3 & 10.1 & 3.2 \\
Aug & 1 & Mid & 0.3 & 1.21 & 12.1 & 12 & 0.1 \\
Aug & 2 & Mid & 0.3 & 1.20 & 12 & 12.8 & 0.8 \\
Aug & 3 & Mid & 0.3 & 1.24 & 13.6 & 8.5 & 5.1 \\
Sep & 1 & Mid & 0.3 & 1.27 & 12.7 & 0.1 & 12.7 \\
\hline
\end{tabular}


Jurnal Tanah dan Sumberdaya Lahan Vol 8 No 1: 135-148, 2021

e-ISSN:2549-9793, doi: 10.21776/ub.jts1.2021.008.1.17

\begin{tabular}{|c|c|c|c|c|c|c|c|}
\hline Bulan & Decade & Stage & Kc & $\begin{array}{c}\text { ETc } \\
\left(\mathrm{mm} \mathrm{day}^{-1}\right)\end{array}$ & $\begin{array}{c}\text { ETc } \\
\left(\mathrm{mm} \mathrm{dec}^{-1}\right)\end{array}$ & $\begin{array}{c}\text { Eff rain } \\
\text { mm dec }^{-1} \text { ) }\end{array}$ & $\begin{array}{l}\text { Irr. Req. } \\
\text { mm dec }^{-1} \text { ) }\end{array}$ \\
\hline Sep & 2 & Mid & 0.3 & 1.31 & 13.1 & 0 & 13.1 \\
\hline Sep & 3 & Mid & 0.3 & 1.31 & 13.1 & 0.1 & 13 \\
\hline Oct & 1 & Mid & 0.3 & 1.31 & 13.1 & 5.6 & 7.5 \\
\hline Oct & 2 & Mid & 0.3 & 1.31 & 13.1 & 8.3 & 4.7 \\
\hline Oct & 3 & Mid & 0.3 & 1.29 & 14.1 & 9 & 5.1 \\
\hline Nov & 1 & Mid & 0.3 & 1.27 & 12.7 & 6.8 & 5.8 \\
\hline Nov & 2 & Mid & 0.3 & 1.25 & 12.5 & 6.4 & 6 \\
\hline Nov & 3 & Mid & 0.3 & 1.18 & 11.8 & 18.1 & 0 \\
\hline Dec & 1 & Mid & 0.3 & 1.12 & 11.2 & 34 & 0 \\
\hline Dec & 2 & Mid & 0.3 & 1.06 & 10.6 & 45.9 & 0 \\
\hline Dec & 3 & Mid & 0.3 & 1.04 & 11.4 & 44.7 & 0 \\
\hline Jan & 1 & Mid & 0.3 & 1.02 & 10.2 & 40.6 & 0 \\
\hline Jan & 2 & Mid & 0.3 & 1.00 & 10.0 & 40.1 & 0 \\
\hline Jan & 3 & Mid & 0.3 & 1.03 & 11.3 & 46.6 & 0 \\
\hline Feb & 1 & Mid & 0.3 & 1.06 & 10.6 & 55.9 & 0 \\
\hline Feb & 2 & Mid & 0.3 & 1.08 & 10.8 & 62.6 & 0 \\
\hline Feb & 3 & Mid & 0.3 & 1.10 & 8.8 & 60 & 0 \\
\hline Mar & 1 & Mid & 0.3 & 1.11 & 11.1 & 56 & 0 \\
\hline Mar & 2 & Mid & 0.3 & 1.12 & 11.2 & 54.2 & 0 \\
\hline Mar & 3 & Mid & 0.3 & 1.12 & 12.3 & 54 & 0 \\
\hline Apr & 1 & Mid & 0.3 & 1.11 & 11.1 & 56.8 & 0 \\
\hline Apr & 2 & Mid & 0.3 & 1.11 & 11.1 & 57.9 & 0 \\
\hline Apr & 3 & Mid & 0.3 & 1.14 & 11.4 & 46.2 & 0 \\
\hline May & 1 & Mid & 0.3 & 1.18 & 11.8 & 30.8 & 0 \\
\hline May & 2 & Mid & 0.3 & 1.21 & 12.1 & 19.4 & 0 \\
\hline May & 3 & Mid & 0.3 & 1.16 & 12.7 & 18.2 & 0 \\
\hline Jun & 1 & Mid & 0.3 & 1.09 & 10.9 & 18 & 0 \\
\hline Jun & 2 & Mid & 0.3 & 1.03 & 10.3 & 15.6 & 0 \\
\hline Jun & 3 & Mid & 0.3 & 1.09 & 10.9 & 13.8 & 0 \\
\hline Jul & 1 & Mid & 0.3 & 1.16 & 11.6 & 11.6 & 0 \\
\hline Jul & 2 & Late & 0.3 & 1.22 & 12.2 & 9.6 & 2.6 \\
\hline Jul & 3 & Late & 0.3 & 1.21 & 13.3 & 10.1 & 3.2 \\
\hline Aug & 1 & Late & 0.3 & 1.21 & 12.1 & 12 & 0.1 \\
\hline Aug & 2 & Late & 0.3 & 1.2 & 7.2 & 7.7 & 0.8 \\
\hline Total & & & & 65.46 & 654.6 & 1694.5 & 86.4 \\
\hline
\end{tabular}

Keterangan $: \mathrm{Kc}=$ Koefisien Tanaman $; \mathrm{ETc}=$ Evapotranspirasi $;$ Eff Rain $=$ Curah Hujan Efektif $;$ Irr Req $=$ Kebutuhan Air Irigasi

Berdasarkan simulasi Cropwat version 8.0 nilai evapotranspirasi (ETc) yang merupakan kebutuhkan air tanaman tertinggi ditunjukan pada bulan September dekade 2 dengan nilai sebesar $1.31 \mathrm{~mm}$ dan nilai kebutuhan air tanaman terendah terjadi pada bulan Januari dekade 2 sebesar $1 \mathrm{~mm}$. Air irigasi tambahan diperlukan kembali oleh tanaman saat Juli dekade 2 hingga Agustus dekade 2. Kebutuhan tambahan air irigasi tertinggi dicapai pada bulan September dekade 2 dengan nilai sebesar 13.1 mm dan terendah pada bulan Agustus dekade 1 sebesar $0.1 \mathrm{~mm}$. apabila simulasi aplikasi Cropwat version 8.0 menunjukkan perlu dilakukan tambahan air irigasi maka curah hujan efektif tidak dapat mencukupi kebutuhan air tanaman. Hal ini terjadi saat musim kemarau tiba dimana curah hujan sudah berkurang dan lengas tanah mengalami penurunan. Jumlah pemberian air irigasi yang dipilih yaitu dikembalikan pada kondisi ketersediaan air dalam tanah (Prijono, 2009). Setiap hari PT. GGP melakukan kegiatan 


\section{Jurnal Tanah dan Sumberdaya Lahan Vol 8 No 1: 135-148, 2021 e-ISSN:2549-9793, doi: 10.21776/ub.jts1.2021.008.1.17}

irigasi untuk lahan seluas 5 ha untuk memenuhi kebutuhan air tanaman nanas berdasarkan standar perusahaan ETc (evaporasi) sebesar 4 $\mathrm{mm}$ hari $^{-1}$ dengan menggunakan alat Gun Sprayer. PT. Great Giant Pineapple melakukan kegiatan irigasi dengan menggunakan alat Gun Sprayer saat terjadi bulan kering yaitu, pada bulan Agustus hingga Oktober ( \pm 90 hari). Volume air irigasi yang digunakan adalah $200 \mathrm{~m}^{3}$ hari-1.

\section{Operasi waduk aktual}

PT. GGP memanfaatkan air waduk khususnya untuk kegiatan irigasi pada bulan kering yaitu dilakukan pada bulan Agustus hingga Oktober
( \pm 90 hari). Data dalam Tabel 5 memberikan informasi bahwa kegiatan irigasi dilakukan pada bulan Agustus hingga Oktober yang mana pada setiap hari pengeluaran air untuk kegiatan irigasi sebesar $200 \mathrm{~m}^{3}$. Pada waduk lokasi 86 memiliki volume waduk yaitu sebesar $11534.16 \mathrm{~m}^{3}$ dan dapat memenuhi kebutuhan air irigasi sampai dengan hari ke 28 dibulan September sedangkan volume pada waduk lokasi 116 sebesar 4861.9 $\mathrm{m}^{3}$ hanya dapat dimanfaatkan sampai dengan bulan Agustus hari ke-25 volume pada waduk lokasi 116 sebesar $4861.9 \mathrm{~m}^{3}$ hanya dapat dimanfaatkan sampai dengan bulan Agustus hari ke-25.

Tabel 5. Penggunaan air waduk aktual.

\begin{tabular}{|c|c|c|c|c|c|c|c|c|c|}
\hline \multirow[t]{2}{*}{ No } & \multicolumn{3}{|c|}{$\begin{array}{l}\text { Jumlah Air Irigasi } \\
\left(\mathrm{m}^{3} \mathrm{hari}^{-1}\right)\end{array}$} & \multicolumn{3}{|c|}{$\begin{array}{c}\text { Tampungan Akhir Waduk } \\
\text { Lokasi } 86\left(\mathrm{~m}^{3}\right)\end{array}$} & \multicolumn{3}{|c|}{$\begin{array}{c}\text { Tampungan Akhir Waduk } \\
\text { Lokasi } 116\left(\mathrm{~m}^{3}\right)\end{array}$} \\
\hline & Agt & Sep & Okt & Agt & Sep & Okt & Agt & Sep & Okt \\
\hline 1 & 200 & 200 & 200 & 11534.16 & 5534.16 & 0.00 & 4861.90 & 0.00 & 0.00 \\
\hline 2 & 200 & 200 & 200 & 11334.16 & 5334.16 & 0.00 & 4661.90 & 0.00 & 0.00 \\
\hline 3 & 200 & 200 & 200 & 11134.16 & 5134.16 & 0.00 & 4461.90 & 0.00 & 0.00 \\
\hline 4 & 200 & 200 & 200 & 10934.16 & 4934.16 & 0.00 & 4261.90 & 0.00 & 0.00 \\
\hline 5 & 200 & 200 & 200 & 10734.16 & 4734.16 & 0.00 & 4061.90 & 0.00 & 0.00 \\
\hline 6 & 200 & 200 & 200 & 10534.16 & 4534.16 & 0.00 & 3861.90 & 0.00 & 0.00 \\
\hline 7 & 200 & 200 & 200 & 10334.16 & 4334.16 & 0.00 & 3661.90 & 0.00 & 0.00 \\
\hline 8 & 200 & 200 & 200 & 10134.16 & 4134.16 & 0.00 & 3461.90 & 0.00 & 0.00 \\
\hline 9 & 200 & 200 & 200 & 9934.16 & 3934.16 & 0.00 & 3261.90 & 0.00 & 0.00 \\
\hline 10 & 200 & 200 & 200 & 9734.16 & 3734.16 & 0.00 & 3061.90 & 0.00 & 0.00 \\
\hline 11 & 200 & 200 & 200 & 9534.16 & 3534.16 & 0.00 & 2861.90 & 0.00 & 0.00 \\
\hline 12 & 200 & 200 & 200 & 9334.16 & 3334.16 & 0.00 & 2661.90 & 0.00 & 0.00 \\
\hline 13 & 200 & 200 & 200 & 9134.16 & 3134.16 & 0.00 & 2461.90 & 0.00 & 0.00 \\
\hline 14 & 200 & 200 & 200 & 8934.16 & 2934.16 & 0.00 & 2261.90 & 0.00 & 0.00 \\
\hline 15 & 200 & 200 & 200 & 8734.16 & 2734.16 & 0.00 & 2061.90 & 0.00 & 0.00 \\
\hline 16 & 200 & 200 & 200 & 8534.16 & 2534.16 & 0.00 & 1861.90 & 0.00 & 0.00 \\
\hline 17 & 200 & 200 & 200 & 8334.16 & 2334.16 & 0.00 & 1661.90 & 0.00 & 0.00 \\
\hline 18 & 200 & 200 & 200 & 8134.16 & 2134.16 & 0.00 & 1461.90 & 0.00 & 0.00 \\
\hline 19 & 200 & 200 & 200 & 7934.16 & 1934.16 & 0.00 & 1261.90 & 0.00 & 0.00 \\
\hline 20 & 200 & 200 & 200 & 7734.16 & 1734.16 & 0.00 & 1061.90 & 0.00 & 0.00 \\
\hline 21 & 200 & 200 & 200 & 7534.16 & 1534.16 & 0.00 & 861.90 & 0.00 & 0.00 \\
\hline 22 & 200 & 200 & 200 & 7334.16 & 1334.16 & 0.00 & 661.90 & 0.00 & 0.00 \\
\hline 23 & 200 & 200 & 200 & 7134.16 & 1134.16 & 0.00 & 461.90 & 0.00 & 0.00 \\
\hline 24 & 200 & 200 & 200 & 6934.16 & 934.16 & 0.00 & 261.90 & 0.00 & 0.00 \\
\hline 25 & 200 & 200 & 200 & 6734.16 & 734.16 & 0.00 & 61.90 & 0.00 & 0.00 \\
\hline 26 & 200 & 200 & 200 & 6534.16 & 534.16 & 0.00 & 0.00 & 0.00 & 0.00 \\
\hline 27 & 200 & 200 & 200 & 6334.16 & 334.16 & 0.00 & 0.00 & 0.00 & 0.00 \\
\hline 28 & 200 & 200 & 200 & 6134.16 & 134.16 & 0.00 & 0.00 & 0.00 & 0.00 \\
\hline 29 & 200 & 200 & 200 & 5934.16 & 0.00 & 0.00 & 0.00 & 0.00 & 0.00 \\
\hline 30 & 200 & 200 & 200 & 5734.16 & 0.00 & 0.00 & 0.00 & 0.00 & 0.00 \\
\hline
\end{tabular}




\section{Jurnal Tanah dan Sumberdaya Lahan Vol 8 No 1: 135-148, 2021 e-ISSN:2549-9793, doi: 10.21776/ub.jts1.2021.008.1.17}

\section{Kinerja waduk}

Kinerja waduk ini dilihat dari kemampuan waduk dalam melakukan fungsinya. Evaluasi tentang kemampuan dari suatu pengoperasian waduk diperlukan adanya indikator atau indeks dari kinerja. Pada lokasi penelitian outflow pada waduk untuk memenuhi kebutuhan air irigasi tanaman nanas dan evaporasi waduk, sedangkan inflow waduk berasal dari besar curah hujan yang masuk kedalam waduk. Waduk lokasi penelitian tidak dialiri oleh aliran anak sungai, sehingga debit aliran dianggap 0 atau tidak ada. Waduk lokasi 86 memiliki fungsi untuk mengirigasi lahan seluas $\pm 23,3$ ha, sementara waduk lokasi 116 untuk mengirigasi luas lahan $\pm 18,82$ ha. Neraca air waduk pada kedua lokasi ini diperhitungkan untuk mengetahui potensi simpanan air di waduk untuk memenuhi kegiatan irigasi PT. GGP. Neraca air waduk dianalisis berdasarkan data total air yang masuk (inflow) yang bersumber dari curah hujan dan total air yang keluar (oufflow) yang digunakan untuk kegiatan irgasi dan kehilangan air akibat evaporasi dari waduk selama satu periode tanam Jan I - Agt II.

Tabel 6. Perhitungan neraca air waduk.

\begin{tabular}{|c|c|c|c|c|c|c|c|c|}
\hline \multirow[t]{2}{*}{ Bulan } & \multicolumn{2}{|c|}{ Inflow } & \multicolumn{2}{|c|}{ Outflow } & \multicolumn{2}{|c|}{$\begin{array}{c}\text { Perubahan } \\
\text { Volume Tampungan }\end{array}$} & \multicolumn{2}{|c|}{$\begin{array}{l}\text { Tampungan } \\
\text { Ahkir Waktu }\end{array}$} \\
\hline & Lok 86 & Lok116 & Lok 86 & Lok116 & Lok 86 & Lok 116 & Lok 86 & Lok116 \\
\hline Jan I & 1493.2 & 678.4 & 1092.2 & 496.2 & 401.0 & 182.2 & 11935.2 & 4861.9 \\
\hline Feb I & 4496.5 & 204.7 & 900.1 & 408.9 & 3596.4 & -204.2 & 15531.5 & 4657.7 \\
\hline Mar I & 3275.9 & 1488.2 & 970.6 & 440.9 & 2305.3 & 1047.3 & 17836.8 & 4861.9 \\
\hline Apr I & 3020.0 & 1372.0 & 1030.2 & 468.0 & 1989.9 & 904.0 & 19826.7 & 4861.9 \\
\hline Mei I & 654.3 & 297.3 & 1119.9 & 508.8 & -465.6 & -211.5 & 19361.1 & 4650.4 \\
\hline Jun I & 432.0 & 196.3 & 976.5 & 443.6 & -544.4 & -247.3 & 18816.7 & 4403.1 \\
\hline Jul I & 276.8 & 125.8 & 2613.1 & 1664.7 & -2336.3 & -1539.0 & 16480.4 & 2864.1 \\
\hline Agt I & 289.4 & 135.3 & 2861.5 & 1794.1 & -2572.1 & -1658.8 & 13908.3 & 1205.3 \\
\hline Sep I & 0.0 & 0.0 & 10554.6 & 7990.0 & -10554.6 & -7990.0 & 3353.6 & 0.0 \\
\hline Okt I & 201.3 & 91.5 & 5887.4 & 4099.2 & -5686.0 & -4007.8 & 0.0 & 0.0 \\
\hline Nov I & 276.8 & 125.8 & 4366.8 & 2955.5 & -4090.0 & -2829.8 & 0.0 & 0.0 \\
\hline Des I & 1442.9 & 655.5 & 1102.3 & 500.8 & 340.6 & 154.7 & 340.6 & 154.7 \\
\hline Jan II & 1493.2 & 678.4 & 1092.2 & 496.2 & 401.0 & 182.2 & 741.6 & 336.9 \\
\hline Feb II & 4496.5 & 204.7 & 900.1 & 408.9 & 3596.4 & -204.2 & 4338.0 & 132.7 \\
\hline Mar II & 3275.9 & 1488.2 & 970.6 & 440.9 & 2305.3 & 1047.3 & 6643.2 & 1179.9 \\
\hline Apr II & 3020.0 & 1372.0 & 1030.2 & 468.0 & 1989.9 & 904.0 & 8633.1 & 2083.9 \\
\hline Mei II & 654.3 & 297.3 & 1119.9 & 508.8 & -465.6 & -211.5 & 8167.5 & 1872.4 \\
\hline Jun II & 432.0 & 196.3 & 976.5 & 443.6 & -544.4 & -247.3 & 7623.1 & 1625.1 \\
\hline Jul II & 276.8 & 125.8 & 2613.1 & 1664.7 & -2336.3 & -1539.0 & 5286.8 & 86.1 \\
\hline Agt II & 289.4 & 135.3 & 3560.5 & 2358.7 & -3271.1 & -2223.4 & 2015.7 & 0.0 \\
\hline
\end{tabular}

Keterangan: Lok $=$ Lokasi

Berdasarkan Tabel 6. dapat dilihat terdapat tampungan volume ahkir waktu yang merupakan penambahan atau pengurangan volume yang terjadi pada waduk yang dipengaruhi oleh perubahan volume tampungan. Perubahan volume tampungan yaitu merupakan inflow waduk dikurangi dengan oufflow waduk. Pada perubahan volume tampungan terjadi defisit air, hal ini karena inflow yang masuk kedalam waduk tidak lebih besar dengan jumlah outflow yang dikeluarkan oleh waduk. Saat defisit air terjadi, volume tampungan waduk memasok jumlah kekurangan air yang tidak dapat dipenuhi oleh inflow waduk yang ditunjukan oleh tampungan volume ahkir waktu. Pada waduk lokasi 86 inflow waduk sudah tidak dapat memenuhi outflow waduk pada bulan Mei I hingga November I dan Mei II hingga Agustus II namun besar kapasitas volume waduk masih dapat merespon kekurangan pasokan air untuk outflow waduk yaitu kegiatan irigasi serta pengurangan air akibat evaporasi kecuali pada bulan Oktober I hingga November I tampungan ahkir sudah menunjukkan nilai 0 . 


\section{Jurnal Tanah dan Sumberdaya Lahan Vol 8 No 1: 135-148, 2021 e-ISSN:2549-9793, doi: 10.21776/ub.jts1.2021.008.1.17}

Waduk lokasi 116 terjadi defisit air karena jumlah inflow tidak dapat memenuhi outflow waduk pada bulan Februari I dan Februari II, Mei I sampai November I, serta Mei II hingga Agustus II sedangkan tampungan volume ahkir pada waduk lokasi 116 yang menunjukkan nilai 0 pada yaitu pada bulan Agustus I hingga November I dan Agustus II. Tampungan volume ahkir yang menunjukkan nilai 0 menandakan bahwa waduk telah mengalami kondisi kering air sehingga waduk tidak dapat memenuhi kebutuhan pasokan air. Keandalan (kemampuan) waduk dapat dihitung dengan menggunakan persamaan (Prijanto dan Ismoyo (2010), : R = 100\% - (n/N x 100\%). Pada Tabel 6 menunjukkan bahwa waduk lokasi 86 terdapat 2 dari 20 bulan sehingga keandalan waduk menjadi 90\% sedangkan pada waduk lokasi 116 menunjukkan terdapat 4 bulan kegagalan tampungan waduk menyediakan air dalam 20 bulan kebutuhan, sehingga keandalan waduk hanya $80 \%$. Keandalan kapasitas waduk dinyatakan dalam persen dengan $\mathrm{n}$ merupakan banyak kejadian kegagalan waduk menyediakan air, dan $\mathrm{N}$ adalah banyaknya data (Taufik dan Setiawan, 2011).

\section{Kesimpulan}

Metode batimetri ini dapat diterapkan pada waduk lokasi 86 yang menunjukkan volume waduk sebesar $11534.16 \mathrm{~m}^{3}$ dengan luas genangan air sebesar $8389 \mathrm{~m}^{2}$. Pada waduk lokasi 116 tidak dapat diterapkan metode batimetri karena alat yang digunakan untuk mengukur titik kedalaman membutuhkan suatu media yaitu air. Waduk lokasi 116 dapat diterapkan metode DEM. Metode DEM dapat menggambarkan elevasi atau topografi pada permukaan bumi. Berdasarkan lengkung kapasitas waduk lokasi 116 memiliki daya tampung maksimum sebesar $4861.9 \mathrm{~m}^{3}$ dengan luas genangan air $3811 \mathrm{~m}^{2}$. Kinerja suatu waduk akan dipengarhui oleh jumlah outflow dan inflow yang terjadi pada waduk serta besar kapasitas waduk. Pada lokasi penelitian yaitu waduk lokasi 86 dan lokasi 116 outflow waduk berasal dari irigasi dan evaporasi waduk dan inflow berasal dari volume hujan yang masuk. Keandalan waduk lokasi 86 dan lokasi 116 yaitu sebesar $90 \%$ dan $80 \%$.

\section{Ucapan Terima Kasih}

Penulis mengucapkan teruima kasih kepada Agritech Improvement PT. Great Giant Pineapple, Lampung Tengah atas dukungannnya dalam pelaksanaan penelitian ini.

\section{Daftar Pustaka}

Croneborg, L., Saito, M., Matera, M., McKeown, D. and van Aardt, J. 2015. Digital Elevation Models. Washington: International Bank for Reconstruction and Development.

Curten, P. 2017. Strategies for Landscape Representation: Digital and Analogue Techniques. New York : Routledge.

Gandhi, S.M. and Sarkar, B.C. 2016. Essentials of Mineral Exploration and Evaluation. Elsevier Inc.

Grasia, D., Sujatmoko, B. dan Rinaldi. 2011. Analisis Kapasitas Tampungan Embung Bulakan untuk Memenuhi Kekurangan Kebutuhan Air Irigasi di Kecamatan Payakumbuh Selatan. Riau : Universitas Riau.

Hamim, M. 201. Pengukuran target strength ikan mas dan ikan lele pada kondisi terkontrol menggunakan quantified fish finder. http:/ / repository.ipb.ac.id/handle/123456789 /47133.

Nurjayanti, R.D. dan Salah, M.B. 2012. Aplikasi Citra ALOS PALSAR Multiwaktu Resolusi $50 \mathrm{~m}$ dalam Identifikasi Tutupan Lahan di Provinsi Lampung. Bogor : Institute Pertanian Bogor.

Prijanto, D. dan Ismoyo, M.J. 2010. Neraca air bendungan teritip Kota Balikpapan Provinsi Kalimantan Timur. Jurnal Teknik Waktu 8(1) : 1412-1867.

Prijono, S. 2009. Aplikasi Cropwat for Windows untuk dasar manajemen sumber daya air di petak tersier. Jurnal Teknik Waktu 7(1) : 88-92

Putra, A.S. 2018. Perencanaan Spillway Pada Waduk Braji untuk Memenuhi Kebutuhan Air Baku Penduduk Desa Braji Kabupaten Sumenep Madura. Surabaya: Institut Teknologi Sepuluh November.

Rachim, D.A. 2007. Dasar-dasar Genesis Tanah. Departemen Ilmu Tanah dan Sumberdaya Lahan, Fakultas Pertanian Institut Pertanian Bogor. Bogor : IPB

Rudianto, A.S. 2019. Studi Rencana Pola Operasi Embung Sukodono Kecamatan Panceng Kabupaten Gresik untuk Kebutuhan Air Baku dan Air Irigasi. Malang : Universitas Muhammadiyah Malang.

Soeprobowati, T.R. 2012. Peta Batimetri Danau Rawapening. BIOMA 14(2):75-78. 
Jurnal Tanah dan Sumberdaya Lahan Vol 8 No 1: 135-148, 2021

e-ISSN:2549-9793, doi: 10.21776/ub.jts1.2021.008.1.17

Suteja, Y., Dirgayusa, I.G.N.P., Widiastuti, dan Putra, I.D.N.N. 2019. Pelatihan penggunaan Fish Finder bagi nelayan Kedonganan guna meningkatkan produksi perikanan. Buletin Udayana Mengabdi 18 (1): 15-22.

Taufik, M. dan Setiawan, A. 2011. Model Pemanfaatan Waduk Wadaslintang Untuk Irigasi dan Non Irigasi. Universitas Muhammadiyah Purworejo.

Tusi, A., Rosadi,B. dan Triana, M. Pendugaan kebutuhan air tanaman nanas (Ananas comosus $\mathrm{L}$. Merr) Menggunakan Cropwat. 2012. Jurnal Irigasi 7(2): 15-20
Widitya, L.M., Sudarto, Putra, A.N. dan Okiyanto, D. 2018. Estimasi kandungan unsur hara kalium dan magnesium pada tanaman nanas (Ananas comosus (L) Merr.) menggunakan Unmanned Aerial Vehicle (UAV) DI PT. Great Giant Pineapple. Jurnal Tanah dan Sumberdaya Lahan 5(2): 979-989. 